UNIVERSITY OF CHITRAL JOURNAL OF LINGUISTICS AND LITERATURE

VOL. 3 | ISSUE I | JAN_ JUNE | 2019

ISSN (E): 2663-1512, ISSN (P): 2617-3611

\title{
Satire and Realism in Jane Austen's Pride and Prejudice: an Interpretative Analysis
}

\author{
Aziz, Ahmad \\ Assistant professor ,Department of English, University of Malakand \\ azizuom@yahoo.com \\ Dr. Tariq Khan \\ Assistant professor, Department of English, University of Malakand \\ Tariqkhan1975@gmail.com \\ Naseer Ahmad \\ M. Phil Scholar. Islamic International University \\ Naseerqazi7@gmail.com
}

\begin{abstract}
Jane Austen is acknowledged for the application of realism and satire in her novels. This paper focuses on the analysis of realism and satire in Jane Austen's Pride and Prejudice; however, her entire oeuvre spotlights the features (of satire and realism) alongside robust feminism: typical of her literary taste and temperament, not necessarily of the Romantic Age which she lived in. Rigorous analysis and realistic observation reveals that the employment of realism and satire in Pride and Prejudice, are quite obvious, in all sorts of aspects including narrative, settings, themes and characters. Analysis of the novel under study leads to the observation that satire and realism go hand in hand in the said novel-intermittently-and thoughtfully. Conclusively, it is observed that Jane Austen's literary life had a tremendous influence on how to subsume realism (primarily through matrimonies) of age and satire on a romantic society (whereby ideals collapse headlong), in Pride and Prejudice.
\end{abstract}

Key Words: Novel, Romantic Age, Satire, Irony, Realism, Jane Austen.

\section{Introduction}

The novel, Pride and Prejudice (1813), revolves around the main and repeated themes of Pride and Prejudice. The two main characters, Mr. Darcy and Elizabeth Bennett, represent these two facades of the novel realistically and sarcastically. Mr. Darcy does not realise how these traits bear upon his character adversely though he is well aware of the presence of these qualities. Elizabeth's statement "... had you behaved in a more gentlemanlike manner" castigates him.

Contrariwise, Elizabeth does not know her quality of discerning people's character has grown into pride. Consequently, she becomes prejudiced against Mr Darcy. She feels it her insult to know that the traits of pride and prejudice are present in her personality. She never expected to possess these qualities. Such anomalies in the novel lead to irony of situation which further highlights the title, 
the main themes in the novel, the social relationship between men and women, and stabilises the issues of pride and prejudice. The sarcasm disparages traditional and conventional social hierarchal structure of Romantic Age and underscores the perception that Jane Austin is a realist in the context of the novel under study. The realism maybe seen in the issues of status and class, the fall of the old aristocracy, the gentry and the yeomanry, the capitalist system, the eternal fight of reason against fancy, the moral issues, match-making (not as a consequence of love, but as a way to assure social and financial security), and women's role in a society with delicate manoeuvring.

\section{Literature Review: An Overview}

In her novels, Jane Austen abundantly uses satire and realism. On close observation, it becomes evident that she has ridiculed the derogatory attitude of society towards women, though she has shown support for the patriarchal values. Some of the features used in writing of this novel are contrast, irony, and the devices used such as letters. The realism created by these features enhances and addresses the issues of the period and through this the main themes in the novel. Hatfield opines that in the $18^{\text {th }}$ century novel, Jane Austen epitomises unison of satire and realism (p.286).

Satire, realism and novel, before the Romantic Age, were regarded opposite genres because satire was considered to represent traditional value, whereas novel compiled recent values. However, Hatfield argues that realism and satire in the due course assimilate into novel. Satirically realistic compositions developed into the novel by $18^{\text {th }}$ century. The satirist contemporaries of Jane Austen were also presents with the Romantic Age novelist (pp.284-85). The remarks are elucidated by Austen's writings, which are related seldom to the age of satire (neo-classical age) and Augustan realism rather than a novelist of Romantic Age.

Sherry argues that realism and irony are employed to deal with many facets of Pride and Prejudice e.g. settings, plot and characters (p.611). in addition, it is inferred by Sherry that irony dressed in realism is among the significant features in the development of the plot of the novel. Sherry describes how both (irony and realism) overshadow the interface among the characters and create prospects for the plot to unfold, simultaneously making fun of the conventional social system present in the novel (pp.614-16). In fact, Hatfield cited from Paulson and described "Pride and Prejudice" as a satire sublimated" " (p.286).

Likewise, Counts argues that some scholars believe the use of irony in Austen's novels as a modus operandi to realism and free style of narration (p.31). Furthermore, Count opines that the amalgamation of these tools generates possibilities for Austen to reconsider communal and individual notions, a trending subject of debate among researchers who investigate Austen's work (p.31). Undeniably, Tuite, states that Austen's irony and her essential sarcastic beliefs serve not to resolve the societal milieu revealed in her novels, but to assault the characteristically prized notion of class, she considers as 'snobbery' (pp. 4-5). Tuite makes a treasured opinion visible in nearly 
UNIVERSITY OF CHITRAL JOURNAL OF LINGUISTICS AND LITERATURE

VOL. 3 | ISSUE I | JAN__ JUNE | 2019

ISSN (E): 2663-1512, ISSN (P): 2617-3611

all of Austen's novels. Subjects like gender and class portrays Jane Austen's association to realism which is unified in the work of fiction (p.10).

According to Mudrick, the use of satire in Pride and Prejudice serves as a means to differentiate social stereotypes, and unique and individual characters. It is claimed that satire is an aspect of Elizabeth's character which helps her in making her insights (pp.120-125). The story is chiefly found through Elizabeth's judgements. Her ironical behaviour distinguishes Elizabeth from other characters in the novel, demonstrating her capacity to reflect on her preferences, while other characters predictably restricted their options. In some cases, they intentionally opt not to notice it because of their gender and class. Mudrick's argument is, further, cemented that satire is employed to differentiate between an eccentric character, like Elizabeth, and characters that lack will and function as the embodiments of social stereotypes, like Mr. Collins and Charlotte Lucas (pp.12324).

Brown deviates from the common opinion about Pride and Prejudice as a satirical work and declares the novel as an ironic comedy (p.37). Brown perceives the novel as a comedy prevalent with sarcasm with qualities that accomplish the comic novel requirements. One such quality is that the main female character should realize the world around her and acknowledge it the way it is. The hopelessness caused by this realization is temporary. This is illustrated in the story when her mother and family almost ruin the chances of marriage for Elizabeth. They did not behave appropriately. However, a joyful ending comes with Mr Darcy's second proposal of marriage. Nonetheless, in satirical realism stories, the hopelessness is severe and merciless (pp.38, 42-43). In brief, heroine is the differentiating element between satirical realism and ironic comedy, and in Pride and Prejudice, Elizabeth fulfils the requirement of poignant farce.

Nevertheless, Brown agrees with the rest of the academics that Jane Austen uses irony, commenting likewise to Counts that Austen uses irony to express realism, especially through description to include information which is otherwise not possible for characters due to their limited, restricted, and almost missing inactive observation (pp.25-26). Like Mudrick, Brown also observes irony as a tool to discern between the general public and individuals, and illustrates that the most elementary kind of irony has been displayed by the opening line. The readers can feel this irony throughout the story of the novel and maybe able to appreciate it as such (p.26).

\section{Significance of Paper}

The study is significant in highlighting the hidden meanings and values within the text. It also illustrates how the surroundings, the literary trends of the time, and author's background influence the text. Jane Austen rubbed on the garb of satire to extend forth the realism of her age, however, the Romantic Age is remarkably characterised by imagination and fancy, and not by satire or/and realism. 
UNIVERSITY OF CHITRAL JOURNAL OF LINGUISTICS AND LITERATURE

VOL. 3 | ISSUE I | JAN_ JUNE | 2019

ISSN (E): 2663-1512, ISSN (P): 2617-3611

\section{Objective(s) of Paper}

The following two main objectives are intended and researched to be achieved:

a. To investigate how satire is applied on Pride and Prejudice for achieving the desired goals of reflecting the true Romantic Society of England.

b. To probe into the realism of the Age that was rarely written about.

\section{Purpose of Paper}

The main purpose of the paper is to explore satire through the use of irony, as modus operandi, to elucidate realism of the Romantic Age present in the novel, Pride and Prejudice.

\section{Scope of Paper}

Analysis of the novel under study has been delimited to those facets of the texts that fulfil purpose of the study i.e., the aspects must be ironical and satirical.

\section{Methodology}

Qualitative research paradigm has been employed because the study is based on in-depth analysis of the text. Information has been gathered from the previous studies conducted on the subject. Interpretative analysis, based on the literature review, would be conducted to answer the research questions.

\section{Discussion}

Analysis of the text reveals several issues to be deliberated. These issues include the exercise of irony, the poignancy of satire, and realism expressed through plot, characters and the settings.

First of all, the novelist has widely used in the test under study. Jane Austen is well-known for her narrative style. This is significant to keep in mind that Austen has blended realism with narrative while using irony as a whip. As the analysis is carried out, it could be observed that the writer has used interactions of characters as the basis for the expression of realism. A mere skimming gives the impression that characterization in Austen's novels should be the focal point. However, an indepth investigation into the text elucidates the mode of narration, general description in the novel and depiction of characters are vital in the employment of irony and implicit realism therein.

The narrative style of Austen enables her to express the sentiments and situations in such a way that provides the appropriate atmosphere for her reader to grasp, allowing them to appreciate the irony used in the novel. In addition, her manner of narrating the events has been cleverly leading the readers through the metaphorical path that Austen wants them to feel; the realism she implies is not merely in the narration or characters' personalities but also in the hidden narrator which is Austen herself-Austen's life, her spinsterhood, the reality of life she experienced. Here the reader 
exclusively knows and understands matters which allow expectation and further prospects of irony in the novel.

Though analysis of the setting is brief, yet it fetches a profound impression on the reader, especially if one is to consider the social milieu in which Austen has written the novel and the society that populates Pride and Prejudice. When the setting of novel is associated with the social and cultural backdrop of the realistic events it is centred on, the readers feel the advantage of the alternatives presented and the offence at the rejection of such offer. Specifically, because of such reaction, she has emphasized the ills of such restrictions on the choices of women and their rights, constructing the effect brimming with irony by portraying and rejecting inequality of genders through characters of the novel under study, permitting the female characters no restrictions in choice that was unusual for women in Austen's society.

Analysis of themes uncovers numerous vital findings with regard to irony and realism in Pride and Prejudice. As the name suggests, the focal premise of the novel is pride and prejudice, which in fact became a means of realism to be tackled cleverly irony. It is noticeable that the theme is employed to interpret gender differences through characters, social and class status, providing each the occasion to see other's weaknesses, concurrently employing irony to underline the presence of blemishes in them alike.

Analysis of characters is significant as they are of the most significant feature of the novel. The actions, thoughts and behaviour of characters are the waves that develop the story, so it is only usual that much satire and realism could be found in them. Difference in the characters often spawned comparison. The comparison in ironical characters befits as an indicant of realism, stressing the anomalies and the shortcomings of upholding the conventional notion, and also depicting Austen's perception of realism.

The intensity of sarcasm in Pride and Prejudice has to be looked at as well. The novel is satirical in a manner that it recurrently takes the societal view of women as second-rate sex and counters it with ridicule and irony. Jane Austen uses irony in such manner that she ridicules the conventional structure of Romantic period, thus underlining the feminist ideology of gender discrimination. Contrariwise, satires are mostly thought to be cogent and harsh in its consequences, it may be argued that Pride and Prejudice does not fully exhort its values as a sardonic piece of literature.

In its place, the adroit manoeuvring of narrative style and irony, in company with characters with peculiar personality traits, have administered to soften the tenor of satire in the novel under reference, providing a more comedic feeling to spotlight the hypothetically heavy ambience of satire. The almost fanciful denouement for the main female character is an evident clue. Irony reaches to its peak when it threatens heroine's social status. The clear veracity of satire sets in for a while. However, as the heroine escapes without enough harmful aftermaths, the effects of 
UNIVERSITY OF CHITRAL JOURNAL OF LINGUISTICS AND LITERATURE

sarcasm are decreased. In short, though satire has infused into the whole novel, it is guised beautifully by sporadic comedic adventures to moderate the farce directed at society.

\section{Critique of Pride and Prejudice}

Pride and Prejudice is well-liked today not only because of its unforgettable characters and proficient story-telling but also the general appealingness of the novel. In the novel, Austen flaunts a consummate exercise of satire, realism, and dialogue that encourage the character growth and intensify the appraisal of the novel.

Austen satire is devastating in its exposure of foolishness and hypocrisy. Self-delusion or the attempt to fool other people is almost always the object of her wit; note how she has Elizabeth say that she hopes she will never laugh at what is wise or good.

The reader finds various forms of exquisite irony: sometimes the characters are unconsciously ironic, as when Mrs Bennett seriously asserts that she would accept any entailed property, though Mr. Collin is willing to; other times, Mr. Bennett and Elizabeth serve to directly express the author's ironic opinion. When Marry Bennett is the only daughter at home and does not have to be compared to her prettier sisters, the author observes that "it was suspected by her father that she submitted to the change without much reluctance." Mr. Bennett turns his wit on himself during the crisis with Wickham and Lydia- "let me once in my life feel how much I have been to blame. I am not afraid of being overpowered by the impression. It will pass away soon enough."

Elizabeth irony is lightened when Jane asks when she began to love Mr. Darcy. "It has been coming on so gradually that I hardly know when it began. But I believe I must date it from my first seeing his beautiful grounds at Pemberley." She can be bitterly cutting, however, on her remark on Darcy's role in separating Bingley and Jane. "Mr. Darcy is uncommonly kind to Mr. Bingley, and takes a prodigious deal of care of him."

The author, independent of any character, uses irony in the narrative parts for some of her sharpest-but often unnoticed-judgement. The Meryton community is glad that Lydia is marrying such a worthless man as Wickham: "and the good-natured wishes for well-doing, which had proceeded before from all the spiteful old ladies in Meryton, lost but little of their spirit in this change of circumstances, because with such a husband, her misery was certain."

Austen uses irony to both provoke whimsical laughter and make veiled, bitter observation. In her hands - and few others are more capable and discriminating-irony is an extremely effective device for moral evaluation.

In Pride and Prejudice, dialogue also plays a significant role. The plot commences with a conversation between Mrs. Bennett and Mr Bennett: "My dear Mr. Bennett,' said his lady to him 
one day, 'have you heard that Netherfield is let at last?"' In the following dialogue, one learns a lot—about Mrs. Bennett's obsession with giving her daughters' hands in marriage, Mr. Bennett satiric and ironic viewpoint with regard to his wife's self-pitying nature. The plot tirelessly set to introduce the family into Bingley group and the discourse has provided the reader details on events of attitudes and plot which manoeuvre the characters.

Dialogue are unfailingly the most lucid and essential aspects of the novel. This is expected as novels were read loudly in Austen's age; therefore quality dialogues were enormously significant. The readers understand of the key developments through the dialogue, and even deep internal changes e.g. Elizabeth's well-known soul-searching scene ("How despicably have I acted!") is related as a person talking to herself.

The speech of each character is fitting individually and is the most impressive manner of exposing the real self of each character. Elizabeth's discourse is straightforward and fresh. The talk of her is cynical, Mr. Collins speech is boring and childish, and Lydia's words are all silliness with no substance.

The incidents that occur in Pride and Prejudice take place to almost all readers - humiliation at the idiocy of one's own flesh and blood, the vacillating emotions of falling in love, and the embarrassment of unexpectedly coming to know a fatal mistake. The feelings of the main characters lead to psychological realism.

Elizabeth and Darcy are naturally angry at each other when Elizabeth initially rejects him. It is natural that she feels pinches of regret and an absolute mindshift with the passage of time. Their every step towards each other has been portrayed with an understanding to the normal feeling of people and how they act/react. In the beautiful and vivid depiction of Elizabeth's self-discovery is a persuasive sight of how a bright feeling individual shifts his/her mind.

However, readers should be at guard when considering realism in Austen's works. Her major strength, as a novelist, is her real weakness. Most of the experiences of life are beyond her scope of writing because her writings are limited to what she knows only. Her male characters are not as skilfully portrayed as her women characters, especially heroines are. Male are mere irregular outlines. She usually avoids extreme passions in her novels. This is observed when she starts to describe the abstract and impersonal voice when Elizabeth says yes to Darcy: Elizabeth "immediately, though not very fluently, gave him to understand that her sentiments had undergone so material a change...as to make her receive with gratitude and pleasure his present assurance." The researchers who disfavour Austen's writings often refer to this absence of acute sentiments as their central argument. Nevertheless, it is hard to refute her gift to create memorable characters, construct well-planned plots, or depict appraisal of society with a piercing judgement. The writings 
UNIVERSITY OF CHITRAL JOURNAL OF LINGUISTICS AND LITERATURE

VOL. 3 | ISSUE I | JAN_ JUNE | 2019

ISSN (E): 2663-1512, ISSN (P): 2617-3611

of Jan Austen hold an enduring excellence, which presents her themes, plots and stories related and appropriate today as they were two centuries ago.

\section{Conclusion}

Conclusively and evidently, the novel Pride and Prejudice reflects not only the biography of Jane Austen herself, but that of the Romantic Age as well with deftness of realism and satire blended together-falling recurrently — through characters, plot, themes, settings, and even narrative style. She has resiliently offended the social stratification and class consciousness (with the tool of irony and satire) through her six novels, particularly in her favourite novel Pride and Prejudice-in which the heroine is her mouthpiece.

\section{References}

Austen, Jane. Pride and Prejudice by Jane Austen. Broughton-in-Furness: Coordination Group Publications Ltd, 2010. Print.

Brown, Julia P. Jane Austen's Novels: Social Change and Literary Form. England: Harvard University Press, 1979. Print.

Counts, Diana M. Jane Austen's Power of Consciousness. Marshall University, Apr. 2003. Web. 08 December 2012.

Hatfield, Glenn. W. "Review: Fiction Plus Satire.” Novel: A Forum on Fiction 2.3 (1969). JSTOR. Web. 09 December 2012.

Merriam-Webster Online Dictionary. Merriam-Webster Online, 2012. Web. 10 December 2012.

Mudrick, Marvin. Jane Austen: Irony as Defence and Discovery. New Jersey: Princeton University Press, 1952. Print.

Sherry, James. "Pride and Prejudice: The Limits of Society." Studies in English Literature, 1500190019.4 (1979): 609-22. JSTOR. Web. 11 December 2012.

Tuite, Clara. "Romantic Austen: Sexual Politics and the Literary Canon." Eighteenth-Century Studies 39.3 (2006): 1-10. JSTOR. Web. 12 December 2012. Literature, Pakistan. This article is an open access article distributed under the terms and conditions of the Creative Commons Attribution (CC BY)

(http://creativecommons.org/licenses/by/4.0/). 